\title{
Inhibitory effect of butein on tumor necrosis factor- $\alpha$-induced expression of cell adhesion molecules in human lung epithelial cells via inhibition of reactive oxygen species generation, NF-kB activation and Akt phosphorylation
}

\author{
JI HOON JANG* , EUN SUN YANG* , KYOUNG-JIN MIN and TAEG KYU KWON \\ Department of Immunology, School of Medicine, Keimyung University, Daegu, Republic of Korea
}

Received July 30, 2012; Accepted September 28, 2012

DOI: $10.3892 /$ ijmm.2012.1158

\begin{abstract}
Cell adhesion molecules play an important role in inflammatory response, angiogenesis and tumor progression. Butein (tetrahydroxychalcone) is a small molecule from natural sources, known to be a potential therapeutic drug with antiinflammatory, anticancer and antioxidant activities. In the present study, we investigated the inhibitory effect of butein on tumor necrosis factor (TNF)- $\alpha$-induced adhesion molecule expression and its molecular mechanism of action. Butein significantly decreased TNF- $\alpha$-induced monocyte (U937) cell adhesion to lung epithelial cells in a dose-dependent manner. Butein also inhibited the protein and mRNA expression of intercellular cell adhesion molecule-1 (ICAM-1) and vascular cell adhesion molecule-1 (VCAM-1) in TNF- $\alpha$-stimulated A549 human lung epithelial cells in a dose-dependent manner. Butein inhibited TNF- $\alpha$-induced reactive oxygen species (ROS) generation and nuclear factor- $\kappa \mathrm{B}(\mathrm{NF}-\kappa \mathrm{B})$ activation in A549 cells; it also inhibited the phosphorylation of MAPKs and Akt, suggesting that the MAPK/Akt signaling pathway may be involved in the buteinmediated inhibition of TNF- $\alpha$-induced leukocyte adhesion to A549 cells. Collectively, our results suggest that butein affects cell adhesion through the inhibition of TNF- $\alpha$-induced ICAM-1 and VCAM-1 expression by inhibiting the NF- $\mathrm{KB} / \mathrm{MAPK} / \mathrm{Akt}$ signaling pathway and ROS generation, thereby, elucidating the role of butein in the anti-inflammatory response.
\end{abstract}

\section{Introduction}

Cell adhesion molecules are cellular surface proteins involved in binding with other cells or with the extracellular matrix

Correspondence to: Professor Taeg Kyu Kwon, Department of Immunology, School of Medicine, Keimyung University, 2800 Dalgubeoldaero, Dalseo-Gu, Daegu 704-701, Republic of Korea

E-mail: kwontk@dsmc.or.kr

${ }^{*}$ Contributed equally

Key words: butein, cell adhesion molecule, anti-inflammation, nuclear factor- $\kappa \mathrm{B}, \mathrm{Akt}$
(ECM) in a process called cell adhesion. These molecules play a critical role in the inflammatory response and tumor progression, which promotes cancer-defining biological processes such growth, survival, migration, and metastasis. Therefore, cell adhesion molecule expression is essential for maintaining cell homeostasis. Among the cell adhesion molecules, intercellular adhesion molecule (ICAM-1) and vascular cell adhesion molecule (VCAM-1) are constitutively expressed on airway endothelial and epithelial barriers during inflammation, which may play a key role in the recruitment and infiltration of leukocytes across the blood vessels at sites of airway inflammation (1-3). ICAM-1 and VCAM-1 have been shown to be upregulated in vascular cells by several pro-inflammatory cytokines such as tumor necrosis factor- $\alpha$ (TNF- $\alpha$ ) (4-6).

Nuclear factor $-\kappa \mathrm{B}(\mathrm{NF}-\kappa \mathrm{B})$ is a well-known transcription factor that regulates the expression of cell adhesion molecules and the development of inflammatory responses by upregulating inflammatory mediators $(7,8)$. Previous reports suggest that TNF- $\alpha$ activates the NF- $\kappa \mathrm{B}$ signaling pathway, which results in the upregulation of cell adhesion molecules, including ICMA-1 and VCAM-1 (9,10). Inhibition of NF- $\kappa$ B activation induces the suppression of TNF- $\alpha$-induced ICAM-1 and VCAM-1 mRNA and protein expression levels (11). Therefore, $\mathrm{NF}-\kappa \mathrm{B}$, the central regulator in adhesion molecule expression, is a more effective target for anti-inflammatory therapy.

Generally regarded as safe, natural compounds have been shown to have antitumor, anti-angiogenic and antiinflammatory effects against several cell types (12). Butein (3,3,2',4'-tetrahydroxychalcone) is a biologically active polyphenol compound derived from numerous plants including the stembark of cashews (Semecarpus anacardium), the heartwood of Dalbergia odorifera, and the traditional Chinese medicinal herbs Caragana jubata and Rhus verniciflua Stokes. Several studies have reported its anti-carcinogenic activities by inhibiting the proliferation of a wide variety of tumor cells (13). Butein can induce growth inhibition through G2/M phase arrest in hepatic cells (14). Butein induces apoptosis through the suppression of STAT-3 gene expression (13) and the sensitization of human hepatoma cells to TRAIL-induced apoptosis via DR5 upregulation and promote $\mathrm{NF}-\kappa \mathrm{B}$ inactivation (15). Recently, it has been reported that butein inhibits the expression of CXC chemokine receptor-4 (CXCR4), a mediator of the 
growth and metastasis of tumors, and thus has the potential to suppress cancer metastasis (16).

Despite evidence that butein can block tumor cell growth and have anti-proliferative activities, the effect of butein on the expression level of specific adhesion molecules (ICAM-1 and VCAM-1) and its anti-inflammatory molecular mechanism have not been elucidated. Therefore, we investigated the effects and the molecular mechanism of butein on TNF- $\alpha$-induced adhesion molecule expression in human lung epithelial cells. We found that butein inhibited TNF- $\alpha$-induced ICAM-1 and VCAM-1 expression and monocyte adhesion through the inhibition of NF- $\kappa \mathrm{B}, \mathrm{MAPK}$ and Akt signaling pathways and reactive oxygen species (ROS) generation.

\section{Materials and methods}

Cell culture and materials. Human lung epithelial A549 cells and human monocyte leukemia U937 cells were obtained from the ATCC (Rockville, MD, USA). The cells were cultured in RPMI-1640 supplemented with $2 \mathrm{mM}$ L-glutamine, $100 \mathrm{U} / \mathrm{ml}$ penicillin, $100 \mu \mathrm{g} / \mathrm{ml}$ streptomycin, and $10 \% \mathrm{FBS}$. The cells were grown at $37^{\circ} \mathrm{C}$ and $5 \% \mathrm{CO}_{2}$ in $95 \%$ humidified air and subcultured twice weekly. Human recombinant $\mathrm{TNF}-\alpha$ was obtained from R\&D Systems (Minneapolis, MN, USA). Anti-VACM-1 and anti-ICAM-1 antibodies were purchased from Santa Cruz Biotechnology, Inc. (Santa Cruz, CA, USA). Anti-phospho-ERK, anti-phospho-JNK, anti-phospho-p38 MAPK, anti-phospho-Akt and anti-NF- $\mathrm{B}-\mathrm{p} 65$ antibodies were purchased from Cell Signaling Technology, Inc. (Boston, MA, USA). PD98059 (ERK inhibitor), SP600125 (JNK inhibitor), and SB203580 (p38 inhibitor) were purchased from Calbiochem (San Diego, CA, USA). Butein and all other reagents were purchased from Sigma-Aldrich.

Western blot analysis. Cells were collected and washed twice with ice-cold phosphate-buffered saline (PBS) pelleted at $1,000 \mathrm{x} \mathrm{g}$ for $5 \mathrm{~min}$. Cellular lysates were prepared by suspending $1 \times 10^{6}$ cells in $100 \mu \mathrm{l}$ of ice-cold lysis buffer (137 mM NaCl, $15 \mathrm{mM}$ EGTA, $0.1 \mathrm{mM}$ sodium orthovanadate, $15 \mathrm{mM} \mathrm{MgCl}_{2}, 0.1 \%$ Triton X-100, $25 \mathrm{mM}$ MOPS, $100 \mu \mathrm{M}$ phenylmethylsulfonyl fluoride, and $20 \mu \mathrm{M}$ leupeptin, adjusted to $\mathrm{pH}$ 7.2) for $20 \mathrm{~min}$ on ice. The extracts were centrifuged at $12,000 \mathrm{x} \mathrm{g}$ for $20 \mathrm{~min}$ at $4^{\circ} \mathrm{C}$. The protein content in the supernatant was measured using a Bio-Rad Protein Assay kit (Bio-Rad, Hercules, CA, USA). The protein lysates were then denatured at $95^{\circ} \mathrm{C}$ for $5 \mathrm{~min}$ after mixing with $5 \mathrm{X}$ SDS-loading buffer and loaded on an SDS polyacrylamide gel for electrophoresis. The proteins were then transferred to Immobilon-P membranes (Millipore Corporation, Bedford, MA, USA). The detection of specific proteins was carried out with an ECL western blotting kit (Millipore Corporation and Amersham Biosciences, Buchinghamshire, UK) according to the manufacturer's instructions.

Cell adhesion assay. A549 cells were grown to 80-90\% confluence in 35-mm plates. Monocyte U937 cells were incubated in RPMI-1640 medium containing 2\% FBS and $10 \mu \mathrm{g} / \mathrm{ml}$ of the fluorescent dye BCECF/AM (485 $\mathrm{nm}$ excitation $/ 535 \mathrm{~nm}$ emission wavelengths; Calbiochem) at $37^{\circ} \mathrm{C}$ for $30 \mathrm{~min}$. After stimulating the A549 cells with $10 \mathrm{ng} / \mathrm{ml}$ of
TNF- $\alpha$ for $6 \mathrm{~h}$ following pretreatment with or without $5 \mu \mathrm{M}$ of butein for $30 \mathrm{~min}$, the cells were washed three times with PBS and re-suspended in phenol red-free RPMI-1640 containing $2 \%$ FBS, and fluorescently labeled U937 cells were added $\left(1 \times 10^{6}\right.$ cells $\left./ \mathrm{ml}\right)$. After incubation for $30 \mathrm{~min}$ at $37^{\circ} \mathrm{C}$, nonadherent U937 cells were removed by washing three times with PBS. U937 cell adhesion was observed under a fluorescence microscope and then counted in 5 randomly selected microscopic fields in each well.

RNA isolation and reverse transcriptase-polymerase chain reaction ( $R T-P C R)$. Total RNA was isolated as previously described (17). Single-strand cDNA was synthesized from $2 \mu \mathrm{g}$ of total RNA using Moloney murine leukemia virus (MMLV) reverse transcriptase (Gibco-BRL, Gaithersburg, MD, USA). The cDNAs for ICAM-1, VCAM-1 and actin were amplified by PCR with specific primers. The sequences of the forward and reverse primers were, respectively: ICAM-1, 5'-AGA GAT GAC CAT GGA GCC-3' and 5'-TCC CTT CTG AGA CCT CTG-3'; VCAM-1, 5'-GAA CAC TCT TAC CTG TGC ACA GCA AC-3' and 5'-GGA GCT GGT AGA CCC TCG CTG G-3'; actin, 5'-GGC ATC GTC ACC AAC TGG GAC-3' and 5'-CGA TTT CCC GCT CGG CCG TGG-3'. The conditions for the PCR reaction were as follows: 26 cycles of $95^{\circ} \mathrm{C}$ for $45 \mathrm{sec}, 56^{\circ} \mathrm{C}$ for $45 \mathrm{sec}$, and $72^{\circ} \mathrm{C}$ for $45 \mathrm{sec}$ for ICAM-1; 26 cycles of $95^{\circ} \mathrm{C}$ for $45 \mathrm{sec}, 62^{\circ} \mathrm{C}$ for $45 \mathrm{sec}$, and $72^{\circ} \mathrm{C}$ for $45 \mathrm{sec}$ for VCAM-1; and 17 cycles of $95^{\circ} \mathrm{C}$ for $30 \mathrm{sec}, 56^{\circ} \mathrm{C}$ for $30 \mathrm{sec}$, and $72^{\circ} \mathrm{C}$ for $35 \mathrm{sec}$ for actin. PCR products were analyzed by agarose gel electrophoresis and visualized by ethidium bromide.

Luciferase reporter gene assay. The $\mathrm{NF}-\kappa \mathrm{B}$ reporter construct was purchased from Clontech (Palo Alto, CA, USA). ICAM-1 and VCAM-1 luciferase plasmids containing regions spanning from -1350 to +45 bp (full length) of the human ICAM-1 promoter and regions spanning -1716 to +119 bp (full length) of the human VCAM-1 promoter were used as previously reported (18). NF- $\kappa$ B reporter plasmids or ICAM-1 or VCAM-1 promoter plasmids were transfected into A549 cells using the Lipofectamine reagent according to the manufacturer's instructions. To assess NF- $\kappa$ B, ICAM-1 or VCAM-1 promoter activity, cells were collected and disrupted by sonication in lysis buffer (25 mM Tris-phosphate, $\mathrm{pH}$ 7.8, 2 mM EDTA, 1\% Triton X-100, and $10 \%$ glycerol). Following centrifugation, aliquots of the supernatants were analyzed with a luciferase assay according to the manufacturer's instructions.

Assessment of NF- $\kappa B-p 65-E G F P$ nuclear translocation.

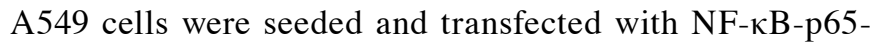
EGFP vector (provided by Dr Jun C.D., GIST, Korea). After $24 \mathrm{~h}$ of transfection, A549 cells were pretreated with $0.5 \mu \mathrm{M}$ of butein for $1 \mathrm{~h}$ at $37^{\circ} \mathrm{C}$ and then exposed to $10 \mathrm{ng} / \mathrm{ml}$ of TNF- $\alpha$ for $1 \mathrm{~h}$. The cells were fixed with $1 \%$ paraformaldehyde on glass slides for $30 \mathrm{~min}$ at room temperature. After washing with PBS, 300 nM of DAPI (4'-6'-diamidino-2-phenylindole; Roche, Germany) was added to the fixed cells for $5 \mathrm{~min}$. The slides were washed and air dried before they were mounted with coverslips with ProLong ${ }^{\circledR}$ antifade mounting medium (Molecular Probes, USA), and they were subsequently examined using a fluorescence microscope. Fluorescence images were observed using a confocal laser scanning microscope 
(LSM 5 Exciter; Carl Zeiss, Jena, Germany) connected to an Axio-observer Z1 inverted microscope using a C-Apochromat $\mathrm{x} 40$ objective. Image analysis was completed with LSM 5 Exciter software (Carl Zeiss).

Measurement of reactive oxygen species. A549 cells were plated in 6-well plates at a density of $4 \times 10^{5}$ cells $/ \mathrm{ml}$, allowed to attach overnight, and treated with TNF- $\alpha(10 \mathrm{ng} / \mathrm{ml})$, butein $(5 \mu \mathrm{M})$, or TNF- $\alpha$ and butein in combination. Intracellular hydrogen peroxide levels were detected by flow cytometry using 2',7'-dichlorodihydrofluorescein diacetate ( $\left.\mathrm{H}_{2} \mathrm{DCFDA}\right)$ (19). This dye is a stable, nonpolar compound that readily diffuses into cells and is hydrolyzed by intracellular esterase to yield DCFH. Hydrogen peroxide produced by cells oxidizes DCFH to the highly fluorescent compound $2^{\prime}, 7^{\prime}$-dichlorofluorescein (DCF). After drug treatment, the cells were treated with $5 \mu \mathrm{M}$ of $\mathrm{H}_{2}$ DCFDA and then incubated at $37^{\circ} \mathrm{C}$ for $20 \mathrm{~min}$. The cells were harvested and washed twice with PBS, and the fraction of DCF-positive cells was observed under a fluorescence microscope (Axiovert 200M; Carl Zeiss).

Statistical analysis. Results are represented as the means \pm SD. The difference between two mean values was analyzed by the Student's t-test and was considered to be statistically significant at $\mathrm{P}<0.05$.

\section{Results}

Butein inhibits TNF- $\alpha$-induced monocyte adhesion to A549 cells. Adhesion of monocytes to endothelial cells is an important step for the initiation and promotion of the inflammatory process. To investigate the effect of butein on the adhesion of monocytes to TNF- $\alpha$-treated lung epithelial cells, we performed a monocyte adhesion assay. A549 cells were pretreated with or without butein for $30 \mathrm{~min}$ before incubation with TNF- $\alpha(10 \mathrm{ng} / \mathrm{ml})$ for $6 \mathrm{~h}$, and then co-cultured with fluorescently labeled human U937 cells. TNF- $\alpha$ treatment significantly increased the adhesion of U937 cells to A549 cells by 6-fold compared with the untreated control cells (Fig. 1A). However, butein significantly inhibited TNF- $\alpha$-induced monocyte adhesion to A549 cells in a dose-dependent manner, and maximum inhibition was estimated to be $\sim 70 \%$ with $5 \mu \mathrm{M}$ butein pretreatment (Fig. 1A). Butein and TNF- $\alpha$ did not affect cellular cytotoxicity when compared with the control cells over a $24 \mathrm{~h}$ incubation period. Cell viability remained $>98 \%$ in all groups assessed by the MTT assay (Fig. 1B).

Butein suppresses the TNF- $\alpha$-induced expression of ICAM- 1 and VCAM-1 in A549 cells. The expression of cell adhesion molecules is related to monocyte adhesion to epithelial cells during inflammation (2). ICAM-1 and VCAM-1 mRNA and protein expression levels were assessed to investigate whether the inhibitory effect of butein on TNF- $\alpha$-induced monocyte adhesion was due to the downregulation of adhesion molecules. A549 cells were incubated with or without various concentrations of butein for 30 min prior to induction with TNF- $\alpha$ $(10 \mathrm{ng} / \mathrm{ml})$ for $12 \mathrm{~h}$. TNF- $\alpha$ significantly increased the protein expression of ICAM-1 and VCAM-1 in A549 cells compared to control-treated cells, and butein effectively inhibited the expression of these molecules in a dose-dependent manner
A

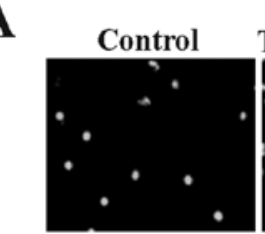

TNF- $\alpha+$

Butein $2.5 \mu \mathrm{M}$

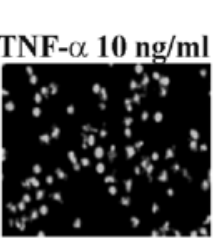

TNF- $\alpha+$

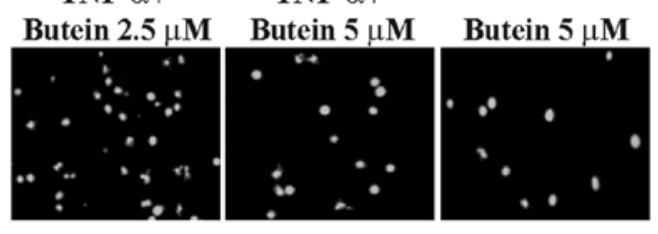

TNF- $\alpha+$

Butein $1 \mu \mathbf{M}$

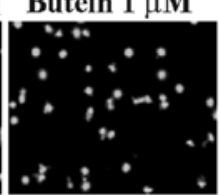

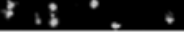

Butein $5 \mu \mathbf{M}$
B

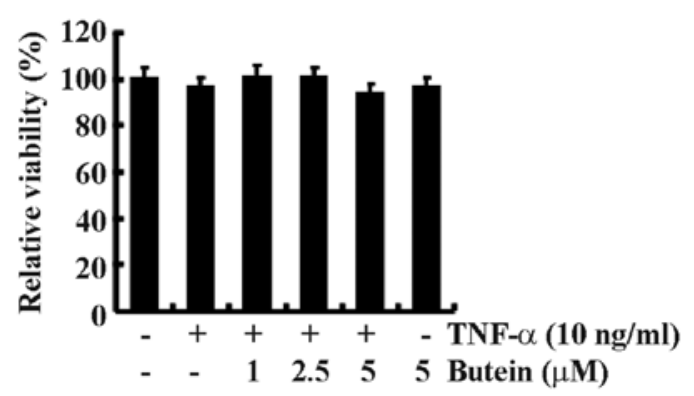

Figure 1. Butein inhibits TNF- $\alpha$-induced monocyte adhesion to A549 cells. (A) A549 cells were stimulated with TNF- $\alpha(10 \mathrm{ng} / \mathrm{ml}) 6 \mathrm{~h}$ after pretreatment with butein $(1,2.5$ and $5 \mu \mathrm{M})$ for $30 \mathrm{~min}$. Fluorescently labeled U937 monocytes were incubated with A549 cells for $60 \mathrm{~min}$, and monocyte adhesion was determined in the images (upper). Adhesion cells were counted and presented as the average of three independent experiments (lower). Statistical significance was determined by Student's t-test ("P $<0.05$ vs. untreated control). (B) A549 cells were pretreated with butein $(1,2.5$ and $5 \mu \mathrm{M})$ for $30 \mathrm{~min}$ before stimulation with TNF- $\alpha(10 \mathrm{ng} / \mathrm{ml})$. Viability was assessed by the MTT assay after $24 \mathrm{~h}$ incubation. Data are presented as the means $\pm \mathrm{SD}$ of three independent experiments and analyzed as the percentage of surviving cells relative to that of the control cells.

(Fig. 2A). Next, we examined the effect of butein on TNF- $\alpha$ induced ICAM-1 and VCAM-1 transcription using RT-PCR analysis. ICAM-1 and VCAM-1 mRNA were expressed at low levels in unstimulated and butein-treated A549 cells, but there was a marked increase in mRNA expression in cells stimulated with TNF- $\alpha$. Butein significantly suppressed the TNF- $\alpha$-induced increase in ICAM-1 and VCAM- 1 mRNA levels in a dose-dependent manner (Fig. 2B). The effect of butein on transcriptional regulation was further investigated by assaying ICAM-1 and VCAM-1 promoter activities. Butein markedly reduced the TNF- $\alpha$-induced luciferase activity in a 

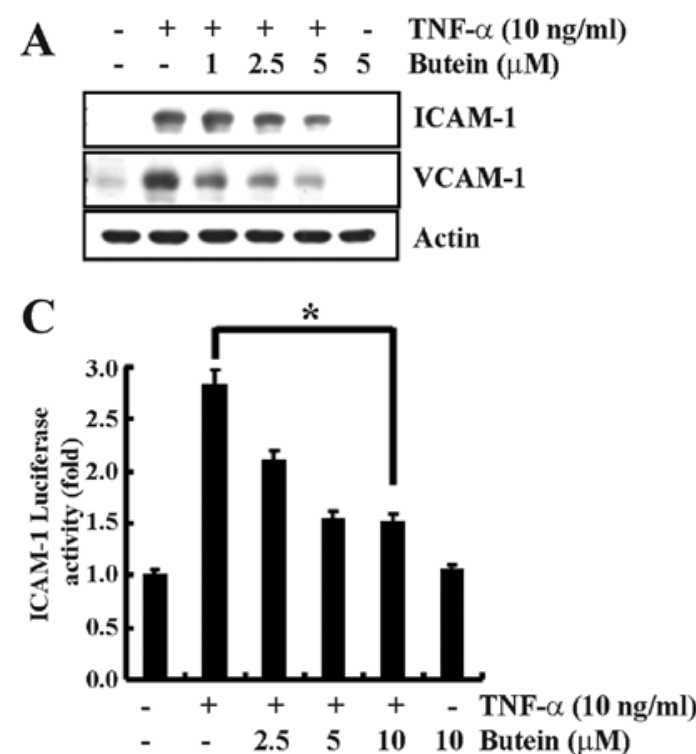

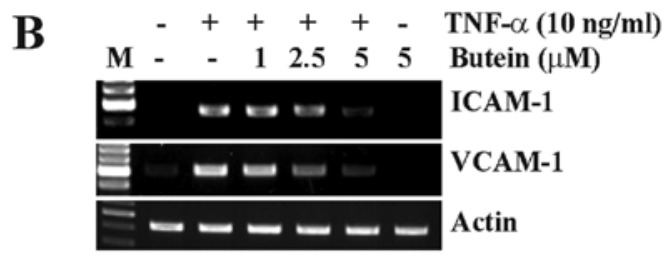

D

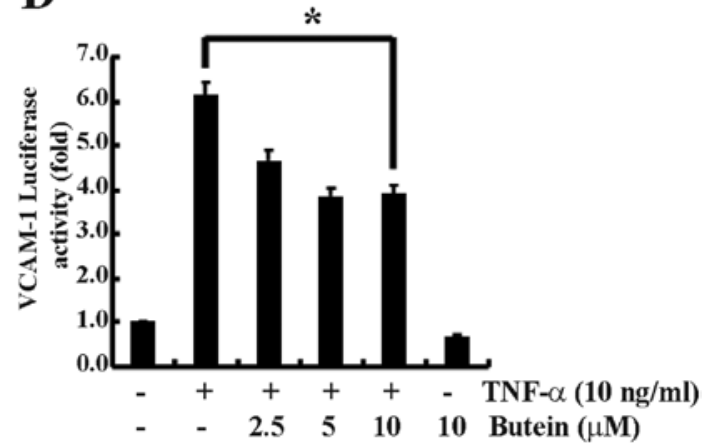

Figure 2. Butein suppresses the TNF- $\alpha$-induced expression of ICAM-1 and VCAM-1 in A549 cells. (A) A549 cells were pretreated with the indicated concentrations of butein before incubation with TNF- $\alpha(10 \mathrm{ng} / \mathrm{ml})$ for $12 \mathrm{~h}$. The cell lysates were analyzed by western blotting with anti-ICAM-1 and anti-VCAM-1 antibodies. Actin served as an internal loading control. (B) A549 cells were pretreated with the indicated concentration of butein before incubating with TNF- $\alpha$ $(10 \mathrm{ng} / \mathrm{ml})$ for $12 \mathrm{~h}$. Total RNA was prepared and analyzed by RT-PCR as described in Materials and methods. ICAM-1 and VCAM-1 mRNA levels were determined by RT-PCR using specific primers. Actin served as an internal loading control. (C and D) To verify the effects of butein on ICAM-1 and VCAM-1 promoter activity, A549 cells were transiently transfected with a luciferase vector containing the full length ICAM-1 (-1350/+45) and VCAM-1 (-1716/+119) promoter regions. Cells were pretreated with the indicated concentration of butein before incubation with TNF- $\alpha$ (10 ng/ml) for $12 \mathrm{~h}$. Cell lysates were analyzed with a luciferase assay according to the manufacturer's instructions. Data are presented as the means \pm SD of three independent experiments. Statistical significance was determined by Student's t-test ( $\mathrm{P}<0.05$ vs. untreated control).

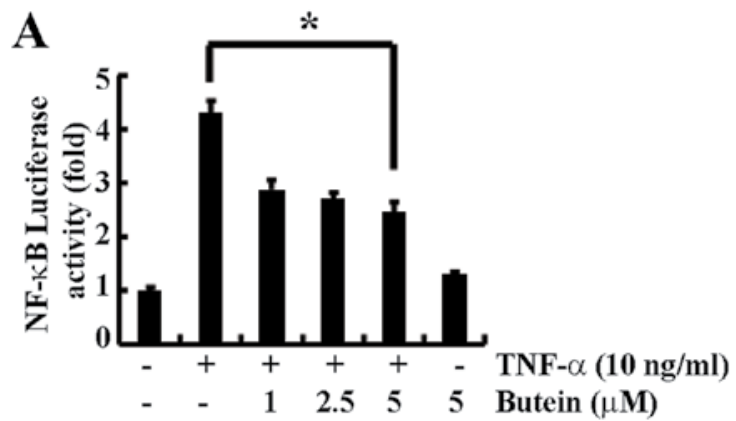

B

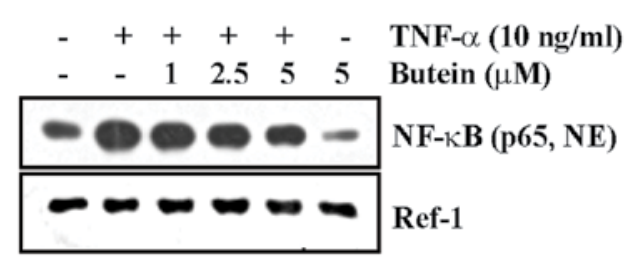

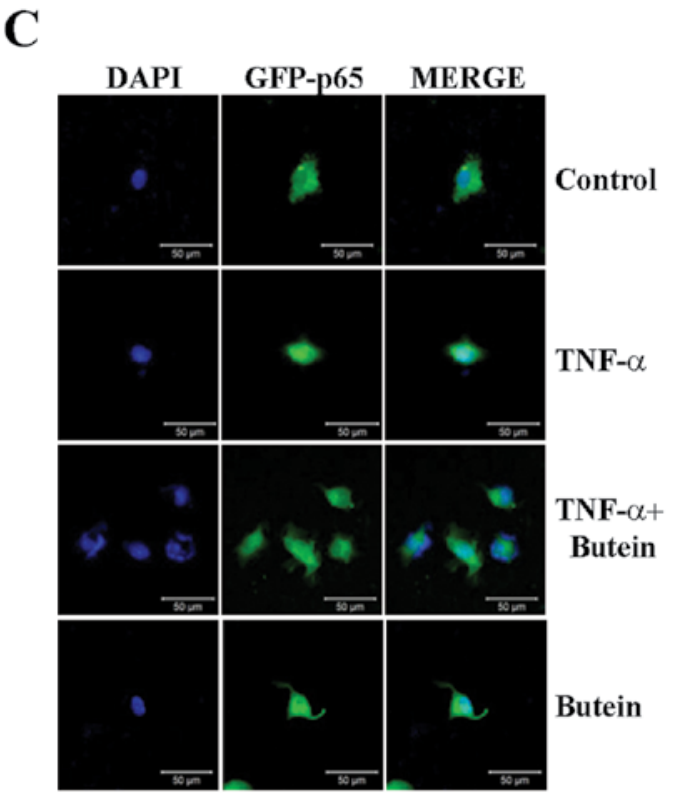

Figure 3. Butein inhibits TNF- $\alpha$-induced NF- $\kappa$ B activation. (A) A549 cells were transiently transfected with a pNF- $\kappa$ B-Luc vector containing four copies of the $\mathrm{NF}-\kappa \mathrm{B}$ binding site and then treated with various concentrations of butein before incubation with TNF- $\alpha$ (10 ng/ml) for $12 \mathrm{~h}$. After cell lysis, NF- $\mathrm{B}$ promoter activity was measured. Data are presented as the means \pm SD of three independent experiments. Statistical significance was determined by the Student's t-test ( $\mathrm{P}<0.05$ vs. untreated control). (B) A549 cells were pretreated with the indicated concentrations of butein before incubation with TNF- $\alpha$ ( $10 \mathrm{ng} / \mathrm{ml})$ for $6 \mathrm{~h}$. After incubation, nuclear fractions were prepared and analyzed by western blotting using an antibody against NF- $\kappa \mathrm{B}-\mathrm{p} 65$ for the detection of NF- $\kappa \mathrm{B}$ nuclear translocation. Ref-1 served as an internal loading control in the nuclear fraction. NE, nuclear fraction. (C) After A549 cells were transfected with an NF- $\kappa \mathrm{B}-$ p65-EGFP expression vector, the cells were pretreated with butein $(5 \mu \mathrm{M})$ for $30 \mathrm{~min}$ and stimulated with TNF- $\alpha$ (10 ng/ml) for $1 \mathrm{~h}$. NF- $\mathrm{BB}$-p65-EGFP nuclear translocation was visualized with a laser scanning confocal microscope.

dose-dependent manner (Fig. 2C and D). These results suggest that butein suppresses ICAM-1 and VCAM-1 mRNA expression and thereby reduces monocyte adhesion to epithelial cells.
Butein inhibits $T N F-\alpha$-induced $N F-\kappa B$ activation. Previous studies have shown that the signaling pathway of $N F-\kappa B$, a well known transcription factor, is involved in the gene 

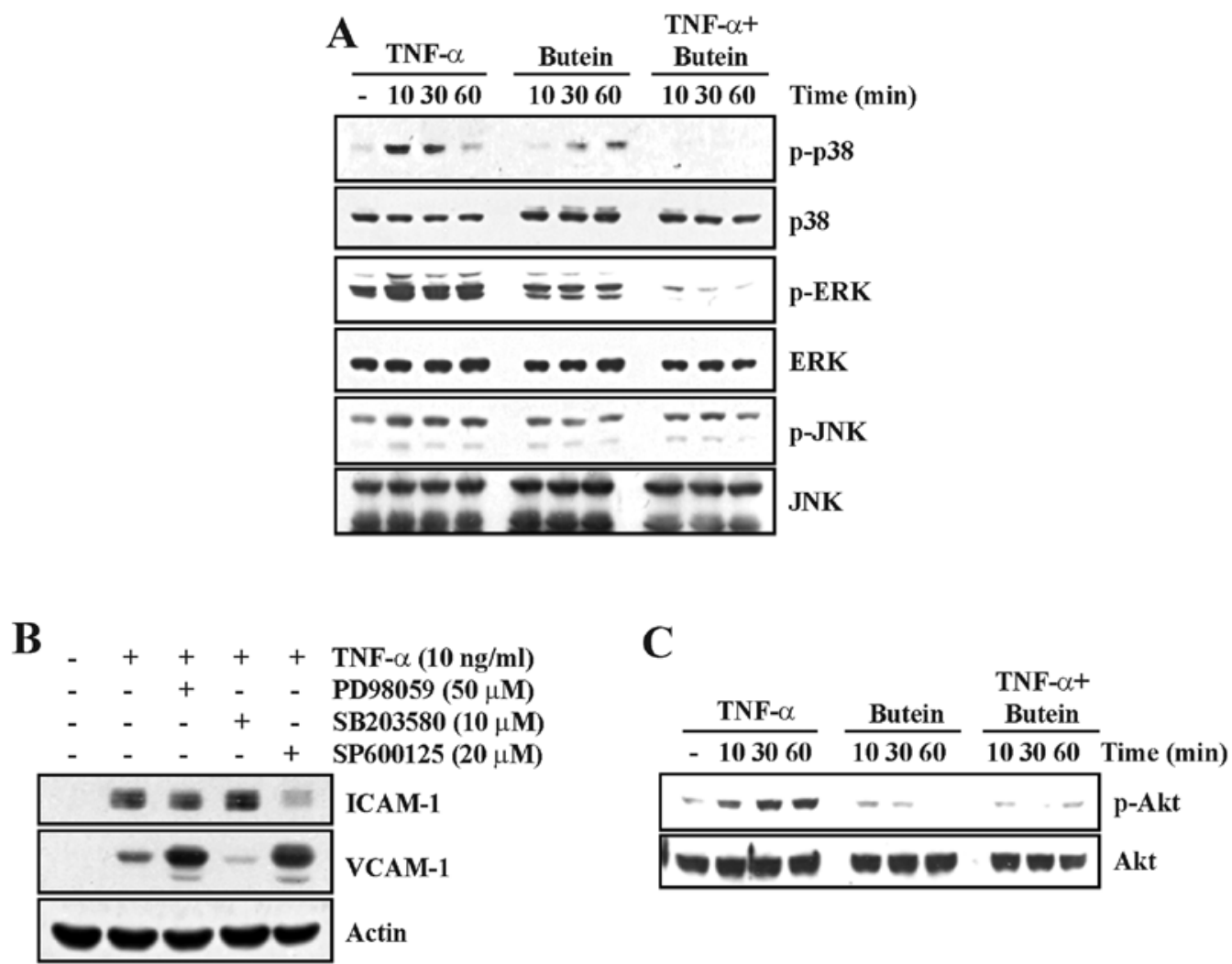

Figure 4. Butein regulates the TNF- $\alpha$-induced phosphorylation of the MAPK and Akt signaling pathways. (A) A549 cells were stimulated with TNF- $\alpha$ $(10 \mathrm{ng} / \mathrm{ml})$ alone, butein $(5 \mu \mathrm{M})$ alone or TNF- $\alpha$ plus butein for the indicated time periods. Equal amounts of cell lysates $(50 \mu \mathrm{g})$ were analyzed by western blotting with antibodies against various activated MAPKs (p-JNK, p-p38 and p-ERK). Total MAPKs served as internal loading controls. A representative result is shown; two additional experiments yielded similar results. (B) A549 cells were pretreated with inhibitors of MAPKs [ERK (PD98059), p38 MAPK (SB203580) and JNK (SP600125)] for $30 \mathrm{~min}$ before incubation with TNF- $\alpha(10 \mathrm{ng} / \mathrm{ml})$ for $12 \mathrm{~h}$. The cell lysates were analyzed by western blotting with anti-ICAM-1 and anti-VCAM-1 antibodies. Actin served as an internal loading control. (C) A549 cells were stimulated with TNF- $\alpha$ (10 ng/ml) alone, butein $(5 \mu \mathrm{M})$ alone or TNF- $\alpha$ plus butein for the indicated time periods. Equal amounts of cell lysates $(50 \mu \mathrm{g})$ were subjected to SDS-PAGE and immunoblotted with an anti-phospho-Akt antibody. The total level of Akt did not change.

expression of various proteins involved in the inflammatory response, including the cell adhesion molecules ICAM-1 and VCAM-1 (20). To confirm the effect of butein on TNF- $\alpha$-induced NF- $\kappa B$-dependent reporter gene expression, we used an NF- $\mathrm{kB}$-luciferase construct, which was generated by introducing four NF- $\kappa \mathrm{B}$ binding sites into the pLuc-promoter vector. We transiently transfected A549 cells with the pNF- $\mathrm{kB}-\mathrm{Luc}$ plasmid and stimulated the cells with TNF- $\alpha(10 \mathrm{ng} / \mathrm{ml})$ either in the presence or absence of butein. An $\sim 4$-fold increase in NF- $\kappa B$ luciferase activity was detected after stimulation with TNF- $\alpha$ for $12 \mathrm{~h}$. Butein significantly reduced the TNF- $\alpha$-induced NF- $\kappa B$ luciferase activity (Fig. 3A). In the unstimulated state, NF- $\mathrm{kB}$ is located in the cytosol and is complexed with the inhibitory protein I $\kappa \mathrm{B} \alpha$. The dissociation of I $\kappa \mathrm{B} \alpha$ from NF- $\kappa \mathrm{B}$ results in NF- $\kappa \mathrm{B}$ activation (21). Therefore, we also performed western blotting to detect the translocation of the NF-кB-p65 subunit. Butein inhibited NF-kB-p65 translocation to the nuclear fraction in a dose-dependent manner (Fig. 3B). In addition, we further analyzed the nuclear translocation of the NF- $\mathrm{kB}-\mathrm{p} 65$ subunit by immunofluorescence. A549 cells were transfected with the NF-кB-p65-EGFP vector for $24 \mathrm{~h}$ and co-treated with butein and TNF- $\alpha$. We found that butein prevented the TNF- $\alpha$ induced nuclear translocation of the NF- $\mathrm{BB}-\mathrm{p} 65$ subunit (Fig. 3C). Therefore, these results suggest that butein inhibits
$N F-\kappa B$ activation through the suppression of TNF- $\alpha$-induced nuclear translocation of NF- $\mathrm{kB}$ in A549 cells.

Butein regulates the TNF- $\alpha$-induced activation of the MAPK and Akt signaling pathways. Since the MAPK pathways are involved in controlling a wide range of cellular responses including growth, differentiation, inflammation and apoptosis, we examined the activation of MAPKs by western blotting using specific anti-phospho-kinase antibodies. TNF- $\alpha$ clearly increased the levels of JNK, p38 MAPK and ERK phosphorylation compared with untreated cells. The TNF- $\alpha$-induced MAPK activation was significantly inhibited by pretreatment with butein (Fig. 4A). To confirm whether MAPK signaling pathways are involved in TNF- $\alpha$-induced ICAM-1 and VCAM-1 expression, we used specific inhibitors of JNK (SP600125), p38 MAPK (SB203580) and ERK (PD98059) on TNF- $\alpha$-stimulated A549 cells. Similar to our earlier results (Fig. 2), pretreatment with inhibitors significantly decreased TNF- $\alpha$-induced ICAM-1 and VCAM-1 expression (Fig. 4B). ICAM-1 was inhibited by treatment with either PD 98059 or SP600125. TNF- $\alpha$-induced VCAM- 1 expression was upregulated by either ERK or JNK inhibition. Notably, VCAM-1 was specifically inhibited by treatment with SB203580.

Akt [protein kinase B (PKB)] is a serine/threonine protein kinase that plays a key role in adhesion molecule expression 
A

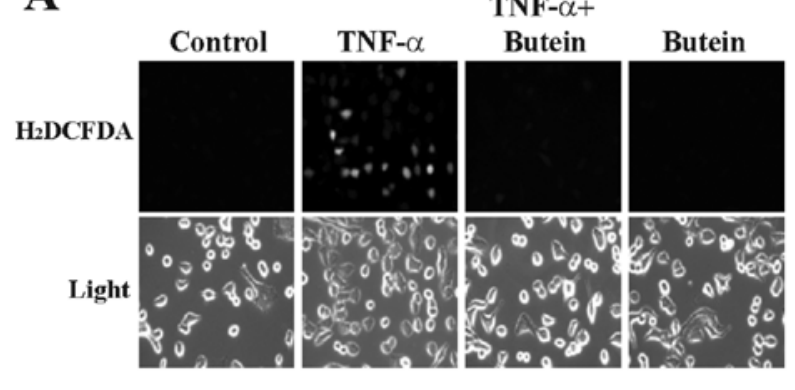

B

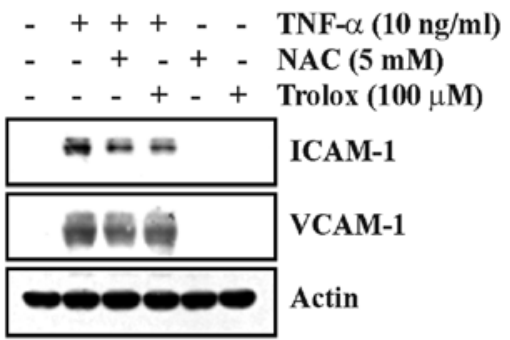

C
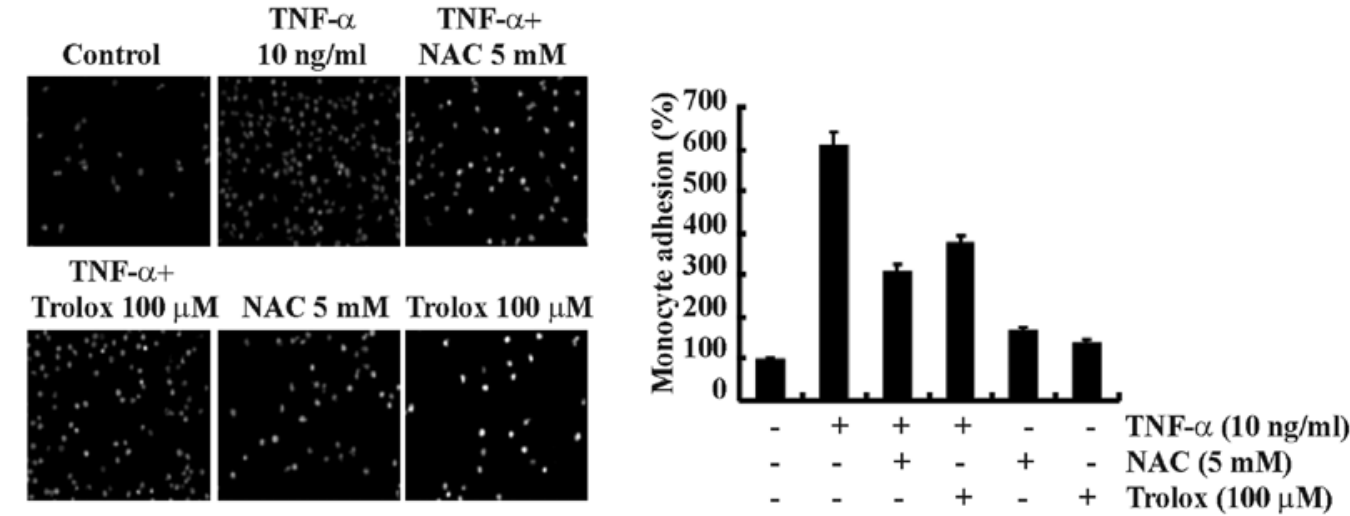

Figure 5. Butein inhibits TNF- $\alpha$-induced ROS generation in A549 cells. (A) To determine the intracellular content of hydrogen peroxide, A549 cells were treated with TNF- $\alpha(10 \mathrm{ng} / \mathrm{ml})$ or butein $(5 \mu \mathrm{M})$ or both for $1 \mathrm{~h}$ and loaded with a fluorescent dye, $\mathrm{H}_{2}$ DCFDA, for another 30 min. The fluorescence in the cells was immediately assayed using a fluorescence microscope. (B) A549 cells were pretreated with NAC (5 mM), Trolox (100 $\mu \mathrm{M})$ for 30 min before incubation with TNF- $\alpha(10 \mathrm{ng} / \mathrm{ml})$ for $12 \mathrm{~h}$. The cell lysates were analyzed by western blotting with anti-ICAM-1 and anti-VCAM-1 antibodies. Actin served as an internal loading control. (C) A549 cells were pretreated with NAC (5 mM) and Trolox (100 $\mu \mathrm{M})$ for $30 \mathrm{~min}$ before incubation with TNF- $\alpha$ (10 ng/ml) for $12 \mathrm{~h}$. Fluorescently labeled U937 monocytes were incubated with A549 cells for 60 min, and monocyte adhesion was determined in the images (left). Adherent cells were counted and represented as an average from three independent experiments (right).

in TNF- $\alpha$-induced epithelial cells (22). To investigate whether butein affects TNF- $\alpha$-induced Akt activation, we examined the effect of butein on the TNF- $\alpha$-induced Akt phosphorylation in A549 cells using western blot analysis. While Akt activation was gradually increased in TNF- $\alpha$-treated A549 cells, a 10 -min butein treatment completely blocked the increase of TNF- $\alpha$-induced Akt phosphorylation (Fig. 4C). These results suggest that butein may reduce TNF- $\alpha$-induced ICAM-1 and VCAM-1 expression by suppressing the phosphorylation of the MAPK and Akt pathway.

Butein inhibits TNF- $\alpha$-induced ROS generation in A549 cells. ROS are important signaling molecules associated with the expression of cell adhesion molecules in response to TNF- $\alpha$ (23). We also found that butein inhibits TNF- $\alpha$-induced NF- $\kappa \mathrm{B}$ activation (Fig. 3). Therefore, we examined the effect of butein on TNF- $\alpha$-induced ROS generation in A549 cells. Butein significantly inhibited the production of TNF- $\alpha$-induced hydrogen peroxide levels, as visualized by fluorescence microscopy (Fig. 5A). To confirm whether ROS generation was involved in TNF- $\alpha$-induced ICAM-1 and VCAM-1 expression, we examined the effect of the antioxidants NAC (N-acetylcysteine) and Trolox on TNF- $\alpha$-stimulated A549 cells. These antioxidant molecules effectively inhibited TNF- $\alpha$-induced ICAM-1 and VCAM-1 expression (Fig. 5B). In addition, TNF- $\alpha$-induced monocyte adhesion to A549 cells was also inhibited by treatment with the antioxidant molecules (Fig. 5C). These results suggest that the inhibition of TNF- $\alpha$ induced ICAM-1 and VCAM-1 expression by butein may be mediated by the inhibition of ROS generation.

\section{Discussion}

The inhibitory effect of many flavonoids on the expression of adhesion molecules is expected to have an anti-inflammatory effect by decreasing leukocyte recruitment. In the present study, we investigated whether butein, an anticancer drug derived from natural sources, is associated with anti-inflammatory activities. Our results showed that butein significantly inhibited both ICAM-1 and VCAM-1 expression levels in TNF- $\alpha$-stimulated A549 cells, and these effects potentially modulated monocyte adhesion to A549 cells. We found that the inhibitory effect of butein on TNF- $\alpha$-treated A549 cells was mediated through the inhibition of $N F-\kappa B$ activation, Akt phosphorylation and ROS generation.

Cell adhesion molecule expression has been reported to be associated with airway inflammation and the migration and recruitment of lymphocytes (24). Numerous studies have shown that TNF- $\alpha$, a pro-inflammatory cytokine, can induce the expression of adhesion molecules, including ICAM-1 and VCAM-1, which contribute to the inflammatory process (25). We also found that TNF- $\alpha$ induced the expression of 
adhesion molecules (ICAM-1 and VCAM-1) and increased monocyte adhesion to A549 cells, which were significantly inhibited by treatment with butein in a dose-dependent manner (Figs. 1 and 2). Our results suggest that butein can prevent TNF- $\alpha$-induced airway inflammation.

$\mathrm{NF}-\mathrm{kB}$ is known to play an important role in the rapid induction of a variety of cytokines (TNF- $\alpha$, MCP-1) and the expression of adhesion molecules (ICAM-1 and VCAM-1) (26). Previous studies have also shown that NF- $\mathrm{kB}$ inhibitory agents (PDTC, curcumin and salicylates) suppress the expression of cell adhesion molecules $(11,27,28)$. In this study, we found that butein significantly inhibited TNF- $\alpha$-induced $\mathrm{NF}-\kappa \mathrm{B}$ promoter activity and the nuclear translocation of NF-кB-p65 (Fig. 3). Therefore, butein may be a potential therapeutic agent for suppressing the NF- $\mathrm{KB}$-dependent inflammatory response.

Several reports suggest that the MAPK (JNK, p38 and ERK) signaling pathways are differentially involved in the anti-inflammatory response and the TNF- $\alpha$-induced expression of adhesion molecules $(29,30)$. Akt has been shown to be involved in NF- $\kappa$ B activation and adhesion molecule expression induced by TNF- $\alpha$ (31). Moreover, butein can attenuate ERK and $\mathrm{p} 38$ MAPK activation to block NF- $\kappa \mathrm{B}$ signaling in human cancer cells $(32,33)$. Therefore, we investigated the effect of butein on TNF- $\alpha$ - induced MAPK and Akt signaling pathway. Our results showed that butein significantly inhibited TNF- $\alpha$ induced Akt phosphorylation and MAPK phosphorylation in lung epithelial A549 cells (Fig. 4). In addition, we previously reported that PI3K/Akt specific inhibitor, LY294002, inhibits TNF- $\alpha$-induced cell adhesion and VCAM-1 expression (34). Therefore, these results suggest that butein may inhibit TNF- $\alpha$-induced ICAM- 1 and VCAM- 1 expression through the inhibition of Akt and MAPK activation.

Reactive oxygen species (ROS), such as the superoxide anion radical $\left(\mathrm{O}_{2}^{-}\right)$, the hydroxyl radical $(\cdot \mathrm{OH})$ and hydrogen peroxide $\left(\mathrm{H}_{2} \mathrm{O}_{2}\right)$, are generated as a result of incomplete reaction of oxygen during aerobic metabolism or environmental stresses such as radiation, UV, heat and several oxidants (35). Many inflammatory cytokines such as TNF- $\alpha$ may generate ROS (36). Adhesion molecule expression has been implicated to occur as a result of ROS-dependent NF- $\mathrm{KB}$ activation, and ROS scavenging agents inhibit the ROS-mediated activation of NF- $\kappa \mathrm{B}(37,38)$. Furthermore, multiple biological properties of polyphenol compounds have been attributed to their antioxidant functions through their influence on intracellular redox status (39). Therefore, we studied the effect of butein on TNF- $\alpha$-induced ROS generation. Our study showed that butein effectively inhibits TNF- $\alpha$-induced ROS generation in A549 cells, which results in the inhibition of ICAM-1 and VCAM-1 expression (Fig. 5). The inhibitory effect of butein on TNF- $\alpha$-induced adhesion molecule expression is due to the inhibition of intracellular ROS generation and relevant signaling pathways.

In conclusion, the present study demonstrated that butein is capable of inhibiting the expression of ICAM-1 and VCAM-1 in TNF- $\alpha$-stimulated A549 cells. The inhibition of adhesion molecule (ICAM-1 and VCAM-1) expression subsequently inhibited monocyte adhesion to TNF- $\alpha$-stimulated A549 cells. We found that the inhibitory effect of butein is mediated through the inhibition of NF- $\mathrm{KB}$, Akt and MAPK activation, and the inhibition of ROS generation also contributed to the inhibition of ICAM-1 and VCAM-1 expression. Thus, butein could be useful in the development of therapeutic drugs against various inflammatory diseases.

\section{References}

1. Polito AJ and Proud D: Epithelia cells as regulators of airway inflammation. J Allergy Clin Immunol 102: 714-718, 1998.

2. Rosseau S, Selhorst J, Wiechmann K, et al: Monocyte migration through the alveolar epithelial barrier: adhesion molecule mechanisms and impact of chemokines. J Immunol 164: 427-435, 2000.

3. Rijcken E, Krieglstein CF, Anthoni C, et al: ICAM-1 and VCAM-1 antisense oligonucleotides attenuate in vivo leucocyte adherence and inflammation in rat inflammatory bowel disease. Gut 51: 529-535, 2002.

4. Burke-Gaffney A and Hellewell PG: Tumour necrosis factoralpha-induced ICAM-1 expression in human vascular endothelial and lung epithelial cells: modulation by tyrosine kinase inhibitors. Br J Pharmacol 119: 1149-1158, 1996.

5. Cybulsky MI, Iiyama K, Li H, et al: A major role for VCAM-1, but not ICAM-1, in early atherosclerosis. J Clin Invest 107: 1255-1262, 2001.

6. Huo Y and Ley K: Adhesion molecules and atherogenesis. Acta Physiol Scand 173: 35-43, 2001.

7. Ghosh S, May MJ and Kopp EB: NF-kappa B and Rel proteins: evolutionarily conserved mediators of immune responses. Annu Rev Immunol 16: 225-260, 1998.

8. Baldwin AS Jr: Series introduction: the transcription factor NF-kappaB and human disease. J Clin Invest 107: 3-6, 2001.

9. Beg AA, Finco TS, Nantermet PV and Baldwin AS Jr: Tumor necrosis factor and interleukin-1 lead to phosphorylation and loss of I kappa B alpha: a mechanism for NF-kappa B activation. Mol Cell Biol 13: 3301-3310, 1993.

10. Chen CC, Rosenbloom CL, Anderson DC and Manning AM: Selective inhibition of E-selectin, vascular cell adhesion molecule-1, and intercellular adhesion molecule-1 expression by inhibitors of I kappa B-alpha phosphorylation. J Immunol 155: 3538-3545, 1995.

11. Pierce JW, Read MA, Ding H, Luscinskas FW and Collins T: Salicylates inhibit I kappa B-alpha phosphorylation, endothelialleukocyte adhesion molecule expression, and neutrophil transmigration. J Immunol 156: 3961-3969, 1996.

12. Newman DJ: Natural products as leads to potential drugs: an old process or the new hope for drug discovery? J Med Chem 51: 2589-2599, 2008.

13. Pandey MK, Sung B, Ahn KS and Aggarwal BB: Butein suppresses constitutive and inducible signal transducer and activator of transcription (STAT) 3 activation and STAT3regulated gene products through the induction of a protein tyrosine phosphatase SHP-1. Mol Pharmacol 75: 525-533, 2009.

14. Moon DO, Kim MO, Choi YH, Hyun JW, Chang WY and Kim GY: Butein induces G(2)/M phase arrest and apoptosis in human hepatoma cancer cells through ROS generation. Cancer Lett 288: 204-213, 2010.

15. Moon DO, Kim MO, Choi YH and Kim GY: Butein sensitizes human hepatoma cells to TRAIL-induced apoptosis via extracellular signal-regulated kinase/Sp1-dependent DR5 upregulation and NF-kappaB inactivation. Mol Cancer Ther 9: 1583-1595, 2010.

16. Chua AW, Hay HS, Rajendran P, et al: Butein downregulates chemokine receptor CXCR4 expression and function through suppression of NF-kappaB activation in breast and pancreatic tumor cells. Biochem Pharmacol 80: 1553-1562, 2010.

17. Chomczynski P and Sacchi N: Single-step method of RNA isolation by acid guanidinium thiocyanate-phenol-chloroform extraction. Anal Biochem 162: 156-159, 1987.

18. Kim I, Moon SO, Kim SH, Kim HJ, Koh YS and Koh GY: Vascular endothelial growth factor expression of intercellular adhesion molecule 1 (ICAM-1), vascular cell adhesion molecule 1 (VCAM-1), and E-selectin through nuclear factor-kappa B activation in endothelial cells. J Biol Chem 276: 7614-7620, 2001.

19. Zegura B, Lah TT and Filipic M: The role of reactive oxygen species in microcystin-LR-induced DNA damage. Toxicology 200: 59-68, 2004.

20. Glass CK and Witztum JL: Atherosclerosis: the road ahead. Cell 104: 503-516, 2001. 
21. Rodriguez MS, Thompson J, Hay RT and Dargemont C: Nuclear retention of IkappaBalpha protects it from signal-induced degradation and inhibits nuclear factor kappaB transcriptional activation. J Biol Chem 274: 9108-9115, 1999.

22. Min JK, Kim YM, Kim SW, et al: TNF-related activationinduced cytokine enhances leukocyte adhesiveness: induction of ICAM-1 and VCAM-1 via TNF receptor-associated factor and protein kinase $\mathrm{C}$-dependent NF-kappaB activation in endothelial cells. J Immunol 175: 531-540, 2005.

23. Kim H, Hwang JS, Woo CH, et al: TNF-alpha-induced upregulation of intercellular adhesion molecule-1 is regulated by a Rac-ROS-dependent cascade in human airway epithelial cells Exp Mol Med 40: 167-175, 2008.

24. Albelda SM, Smith CW and Ward PA: Adhesion molecules and inflammatory injury. FASEB J 8: 504-512, 1994.

25. Lee $\mathrm{G}, \mathrm{Na} \mathrm{HJ}$, Namkoong $\mathrm{S}$, et al: 4-O-methylgallic acid downregulates endothelial adhesion molecule expression by inhibiting NF-kappaB-DNA-binding activity. Eur J Pharmacol 551: 143-151, 2006.

26. Tak PP and Firestein GS: NF-kappaB: a key role in inflammatory diseases. J Clin Invest 107: 7-11, 2001.

27. Marui N, Offermann MK, Swerlick R, et al: Vascular cell adhesion molecule-1 (VCAM-1) gene transcription and expression are regulated through an antioxidant-sensitive mechanism in human vascular endothelial cells. J Clin Invest 92: 1866-1874, 1993.

28. Singh S and Aggarwal BB: Activation of transcription factor NF-kappa B is suppressed by curcumin (diferuloylmethane) [corrected]. J Biol Chem 270: 24995-25000, 1995.

29. Ho AW, Wong CK and Lam CW: Tumor necrosis factor-alpha upregulates the expression of CCL2 and adhesion molecules of human proximal tubular epithelial cells through MAPK signaling pathways. Immunobiology 213: 533-544, 2008.

30. Ju JW, Kim SJ, Jun CD and Chun JS: p38 kinase and c-Jun $\mathrm{N}$-terminal kinase oppositely regulates tumor necrosis factor alpha-induced vascular cell adhesion molecule-1 expression and cell adhesion in chondrosarcoma cells. IUBMB Life 54: 293-299, 2002.
31. Kang JS, Yoon YD, Han MH, et al: Glabridin suppresses intercellular adhesion molecule-1 expression in tumor necrosis factor-alpha-stimulated human umbilical vein endothelial cells by blocking sphingosine kinase pathway: implications of Akt, extracellular signal-regulated kinase, and nuclear factor-kappaB/ Rel signaling pathways. Mol Pharmacol 69: 941-949, 2006.

32. Zhang L, Chen $\mathrm{W}$ and $\mathrm{Li} \mathrm{X}$ : A novel anticancer effect of butein: inhibition of invasion through the ERK1/2 and NF-kappa B signaling pathways in bladder cancer cells. FEBS Lett 582: 1821-1828, 2008.

33. Lee SH, Seo GS, Jin XY, Ko G and Sohn DH: Butein blocks tumor necrosis factor alpha-induced interleukin 8 and matrix metalloproteinase 7 production by inhibiting p38 kinase and osteopontin mediated signaling events in HT-29 cells. Life Sci 81: 1535-1543, 2007.

34. Oh JH and Kwon TK: Withaferin A inhibits tumor necrosis factor-alpha-induced expression of cell adhesion molecules by inactivation of Akt and NF-kappaB in human pulmonary epithelial cells. Int Immunopharmacol 9: 614-619, 2009.

35. Cerutti PA: Prooxidant states and tumor promotion. Science 227: 375-381, 1985

36. Sprague AH and Khalil RA: Inflammatory cytokines in vascular dysfunction and vascular disease. Biochem Pharmacol 78: 539-552, 2009.

37. Qin P, Tang X, Elloso MM and Harnish DC: Bile acids induce adhesion molecule expression in endothelial cells through activation of reactive oxygen species, NF-kappaB, and p38. Am J Physiol Heart Circ Physiol 291: H741-H747, 2006.

38. Schreck R, Meier B, Mannel DN, Droge W and Baeuerle PA: Dithiocarbamates as potent inhibitors of nuclear factor kappa $B$ activation in intact cells. J Exp Med 175: 1181-1194, 1992.

39. Lu JM, Lin PH, Yao Q and Chen C: Chemical and molecular mechanisms of antioxidants: experimental approaches and model systems. J Cell Mol Med 14: 840-860, 2010. 